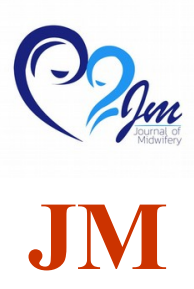

Volume 8 No. 2 (Oktober 2020)

(C) The Author(s) 2020

\title{
HUBUNGAN STATUS IMUNISASI DAN RIWAYAT PENYAKIT INFEKSI DENGAN KEJADIAN STUNTING PADA BALITA: STUDI RETROSPEKTIF
}

\section{RELATIONSHIP OF IMMUNIZATION STATUS AND HISTORY OF INFECTIOUS DISEASE WITH STUNTING INCIDENCE IN TODDLERS: RETROSPECTIVE STUDY}

\author{
AGUNG SUTRIYAWAN, RATNA DIAN KURNIAWATI, \\ SRI RAHAYU, JULIUS HABIBI \\ PROGRAM STUDI S1 KESEHATAN MASYARAKAT, \\ UNIVERSITAS BHAKTI KENCANA \\ FAKULTAS ILMU KESEHATAN, UNIVERSITAS DEHASEN BENGKULU \\ Email: agung.epid@gmail.com
}

\begin{abstract}
ABSTRAK
Pendahuluan: Permasalahan gizi pada balita balita masih menjadi nomor satu di wilayah dunia, sepertihalnya stunting. Stunting dipengaruhi secara langsung oleh penyakit infeksi dan imunisasi merupakan cara untuk meningkatkan kekebalan tubuh seseorang supaya tidak terkena penyakit. Tujuan penelitian ini untuk mengetahui hubungan status imunisasi dan riwayat penyakit infeksi dengan kejadian stunting. Metode:Jenis penelitian yang digunakan adalah studi analitik dengan desain kasus-kontrol. Populasi dalam penelitian ini adalah balita yang ada diwilayah kerja Puskesmas Citarip Kota Bandung. Jumlah sampel kasus sebanyak 45 responden dan sampel kontrol sebanyak 90 responden. Teknik pengambilan sampel yang digunakan adalah purposive sampling, dengan kriteria balita stunting dari golongan umur 24-59. Data yang dikumpulkan adalah data sekunder, dimana data tersebut dikumpulkan oleh pemegang program gizi pada saat penimbangan balita di seluruh posyandu. Analisis data menggunakan uji chisquare. Hasil:Variabel yang berhubungan dengan kejadian stunting adalah riwayat penyakit infeksi $(\mathrm{p}=0,000), \mathrm{OR}=7,073(3,174-15,758)$, dan variabel yang tidak berhubungan adalah status imunisasi $(p=0,056)$. Kesimpulan:Tidak ada hubungan yang signifikan antara status imunisasi dengan kejadian stunting pada balita. Ada hubungan yang signifikan antara riwayat penyakit infeksi dengan kejadian stunting pada balita.
\end{abstract}

Kata Kunci: Stunting, riwayat penyakit infeksi, imunisasi

\begin{abstract}
Introduction: Nutrition problems in toddlers are still the number one in the world, as is stunting. Stunting directly affected by infectious diseases and immunizations is a way to boost a person's immunity so as not to get the disease.The objectives of this study is to find out the relationship
\end{abstract}


of immunization status and history of infectious diseases with the incidence of stunting. Method: The type of research used is analytical studies with case-control design. The population in this study is toddlers who are in the working area of Citarip Health Center in Bandung. The sample number of cases was 45 respondents and a control sample of 90 respondents. The sampling technique used is purposive sampling, with the criteria of stunting toddlers from the age group 24-59. The data collected is secondary data, where it is collected by nutrition program holders at the time of weighing toddlers throughout posyandu. Analyze data using chi-square test. Result: variables associated with stunting events are the history of infectious diseases $(p=0.000)$, OR $=7,073(3,174-15,758)$, and unrelated variables are immunization status $(\mathrm{p}=0.056)$. Conclusion: There is no significant link between immunization status and stunting events in toddlers. There is a significant link between the history of infectious diseases and the incidence of stunting in toddlers.

\section{Keywords: Stunting, history of infectious diseases, immunization}

\section{PENDAHULUAN}

Permasalahan gizi pada balita balita masih menjadi nomor satu di dunia, diantaranya stunting, wasting dan overweight. Stunting merupakan masalah kesehatan gizi yang menunjukkan kondisi gagal tumbuh pada balita akibat kekurangan gizi kronis. Stunting menyebabkan implikasi jangka panjang yaitu berkurangnya perkembangan kognitif dan fisik, tes kinerja lebih rendah, pengeluaran rumah tangga perkapita lebih rendah, kemungkinan peningkatan hidup dalam kemiskinan, peningkatan risiko tenaga kerja terhambat dan asfiksia saat melahirkan, serta peningkatan risiko degeneratif seperti obesitas, diabetes mellitus, penyakit jantung, stroke, hipertensi, dan kanker.

Kekurangan gizi pada masa Golden Period (0-2 tahun) akan menyebabkan sel otak balita tidak tumbuh sempurna. Hal ini disebabkan karena 80-90\% jumlah sel otak terbentuk semenjak masa dalam kandungan sampai usia 2 tahun. Stunting merupakan masalah yang kompleks seperti yang digambarkan oleh berbagai kerangka kerja konseptual, yang berfokus pada kekurangan gizi pada anak, kekurangan gizi pada ibu, dan keamanan pangan. Penyebab umum kejadian stunting pada anak di Indonesia adalah tinggi badan dan pendidikan ibu, lahir prematur dan panjang lahir, ASI eksklusif selama 6 bulan, dan status sosial ekonomi rumah tangga. Selain itu penggunaan air bersi, anak dari masyarakat pedesaan sangat rentan terhadap stunting, anak laki-laki jauh lebih mungkin mengalami stunting dibandingkan anak perempuan di seluruh Indonesia. Penelitian sebelumnya menyatakan bahwa tidak lengkapnya imunisasi dapat menyebabkan imunitas balita menjadi lemah, sehingga mudah untuk terserang infeksi. Balita yang mengalami infeksi jika dibiarkan dapat berisiko terjadinya stunting.

Buruknya status gizi memiliki dampak negatif jangka pendek dan jangka panjang. Dampak negatif jangka pendek adalah terganggunya perkembangan otak, kecerdasan, gangguan pertumbuhan fisik dan gangguan metabolisme dalam tubuh. Sedangkan, dalam jangka panjang dampak negatif yang dapat ditimbulkan adalah menurunnya kekebalan tubuh sehingga mudah sakit dan risiko tinggi munculnya penyakit tidak menular seperti diabetes, obesitas, jantung dan pembuluh darah, kanker, stroke dan disabilitas pada usia tua.

Tercapainya target prevalensi stunting World Health Assembly (WHA) memastikan menurunnya angka stunting sebanyak $40 \%$ dari prevalensi 2013 yaitu $22 \%$ pada tahun 2015 dan Tujuan Pembangunan Berkelanjutan (TPB) yaitu eliminasi semua bentuk kekurangan gizi pada tahun 2030.(10) Pemerintah menetapkan stunting sebagai salah satu program prioritas. Berdasarkan Peraturan Menteri Kesehatan Nomor 39 Tahun 2016 tentang Pedoman 
Penyelenggaraan Program Indonesia Sehat dengan Pendekatan Keluarga, upaya yang dilakukan untuk menurunkan prevalensi stunting pada balita, diantaranya pemantauan pertumbuhan balita, menyelenggarakan kegiatan Pemberian Makanan Tambahan (PMT), menyelenggarakan stimulasi dini perkembangan balita dan memberikan pelayanan kesehatan yang optimal.

Berdasarkan data World Health Organization (WHO) menjelaskan bahwa pada tahun 2018 terdapat $21,9 \%$ balita dibawah lima tahun (balita) didunia mengalami stunting. Lebih dari setengahnya balita stunting berasal dari Asia sebesar 55\%. Dari 81,7 juta balita stunting di Asia, proporsi terbanyak berasal dari Asia Selatan sebesar $57,9 \%$, dan yang kedua dari Asia Tenggara sebesar $14,4 \%$. Proporsi balita stunting di Indonesia tertinggi kedua sebesar 36,4\% Salah satu negara di Asia Tenggara dengan prevalensi stunting tertinggi adalah adalah Indonesia sebesar 36,4\% setelah Timor leste sebesar 57,5\%.(1)

Prevalensi stunting di Indonesia menurutRiset Kesehatan Dasar 2018 sebesar $30,8 \%$ terjadi penurunan dari tahun 2013 sebesar 37,2\% dan pada tahun 2007 sebesar $36.8 \%$. Pada tahun 2018 prevalensi stunting lebih tinggi dibandingkan dengan permasalahan gizi pada balita lainnya seperti gizi buruk, gizi kurang gizi kurus dan kegemukan. Proporsi balita stunting di Indonesia tertinggi di Nusa Tenggara Timur (42,6\%), Sulawesi Barat (41,6\%)dan Aceh $(37,1 \%)$. Prevalensi stunting Jawa Barat sebesar 31,1\%.

Data stunting pada Dinas Kesehatan Kota Bandung, menunjukkan bahwa Kecamatan tertinggi dengan kejadian stunting berada di Kecamatan Batununggal sebanyak 688 balita, yang kedua berada di Kecamatan Bandung Kulon dan Cibiru sebanyak 590 balita dan yang ketiga berada di Kecamatan Bojongloa Kaler sebanyak 458 balita. Kecamatan Bojongloa Kaler terdiri dari 5 kelurahan yaitu Kopo, Suka Asih, Babakan Asih, Jamika dan Babakan Tarogong. Kelurahan Kopo dan Suka Asih termasuk kedalam wilayah kerja UPT Puskesmas Citarip. Bojongloa Kaler menjadi kecamatan ketiga tertinggi di Kota Bandung dengan jumlah kasus sebanyak 458 balita dari total 5.852 balita. Tahun 2019, jumlah kasus stunting pada wilayah kerja UPT Puskesmas Citarip ini telah mengalami penurunan dari total 746 kasus balita stunting. Namun Kecamatan Bojongloa Kaler masih termasuk ke dalam 3 Kecamatan tertinggi dari tahun 2017-2019 di Kota Bandung. Berdasarkan latar belakang dan permasalahan tersebut maka dibutuhkan penelitian lebih lanjut untuk mengetahui hubungan status imunisasi dan penyakit infeksi dengan kejadian stunting di UPT Puskesmas Citarip.

\section{METODE PENELITIAN}

Jenis penelitian yang digunakan adalah studi analitik dengan desain kasus kontrol. Desain ini digunakan untuk mengetahui hubungan status imunisasi dan riwayat penyakit infeksi dengan kejadian stunting. Populasi kasus dalam penelitian ini adalah seluruh balita stunting dengan total 117 balita. Sedangkan populasi kontrol dalam penelitian ini adalah seluruh balita tidak stunting sebanyak 2.544 balita. Teknik pengambilan sampel yang digunakan adalah purposive sampling, dengan kriteria: Balita stunting dari golongan umur 24-59 dan tercatat pada buku KIA. Data yang dikumpulkan adalah data sekunder, dimana data tersebut dikumpulkan oleh pemegang program gizi pada saat penimbangan balita di seluruh posyandu. Dari hasil data tersebut kemudian dilakukan proses pengolahan data untuk memisahakan data balita dengan golongan umur yang sesuai dengan kriteria. Analisis yang digunakan adalah analisis univariat yaitu untuk mengetahui status imunisasi, riwayat penyakit infeksi dan kejadian stunting. Dalam analisa ini hanya menghasilkan distribusi frekuensi dan persentase dari setiap variabel. Analisis selanjutnya menggunakan uji chisquare untuk mengetahui hubungan status imunisasi, riwayat penyakit infeksi dengan kejadian stunting. Software yang digunakan 
untuk uji statistic adalah SPSS versi 25.

HASIL PENELITIAN

Tabel 1. Gambaran Kejadian Stunting Pada Balita di Wilayah Kerja Puskesmas Citarip Kota Bandung

\begin{tabular}{ccc}
\hline Stunting & Jumlah & \% \\
\hline Stunting & 45 & 33,4 \\
\hline Tidak Stunting & 90 & 66,7 \\
\hline Total & $\mathbf{1 3 5}$ & $\mathbf{1 0 0}$ \\
\hline
\end{tabular}

Hasil yang disajikan pada tabel 1 menunjukkan bahwa sebagian besar responden dalam penelitian ini adalah balita yang tidak menderita stunting $(66,7 \%)$.

Tabel 2. Gambaran Status Imunisasi, Riwayat Penyakit Infeksi Pada Balita di Wilayah Kerja Puskesmas Citarip Kota Bandung

\begin{tabular}{ccc}
\hline Variabel & Frekuensi & \% \\
\hline Status Imunisasi & & \\
\hline Tidak Lengkap & 79 & 58,5 \\
\hline Lengkap & 56 & 41,5 \\
\hline $\begin{array}{c}\text { Riwayat Penyakit } \\
\text { Infeksi }\end{array}$ & \\
\hline Ada Riwayat & 45 & 33,3 \\
\hline Tidak Ada Riwayat & 90 & 66,7 \\
\hline Total & $\mathbf{1 3 5}$ & $\mathbf{1 0 0}$ \\
\hline
\end{tabular}

Hasil yang disajikan pada tabel 2 menunjukkan bahwa sebagian besar responden dengan status imunisasi tidak lengkap $(58,5 \%)$, sepertiga responden tidak memiliki riwayat penyakit infeksi $(66,7 \%)$,

Tabel 3. Hubungan Status Imunisasi dan Riwayat Penyakit Infeksi dengan Kejadian Stunting Pada Balita di Wilayah Kerja Puskesmas Citarip Kota Bandung

\begin{tabular}{|c|c|c|c|c|c|c|}
\hline \multirow{3}{*}{ Variabel } & \multicolumn{4}{|c|}{ Stunting } & \multirow{3}{*}{ P-value } & \multirow{3}{*}{$\begin{array}{c}\text { OR }(95 \% \\
\text { CI) } \\
\text { Lower - } \\
\text { Upper }\end{array}$} \\
\hline & \multicolumn{2}{|c|}{ Kasus } & \multicolumn{2}{|c|}{ Kontrol } & & \\
\hline & $\begin{array}{c}n=4 \\
5\end{array}$ & $\%$ & $\begin{array}{c}n=9 \\
0\end{array}$ & $\%$ & & \\
\hline $\begin{array}{c}\text { Status } \\
\text { Imunisasi }\end{array}$ & & & & & & \\
\hline $\begin{array}{c}\text { Tidak } \\
\text { Lengkap }\end{array}$ & 32 & 71,1 & 47 & 52,2 & 0,056 & $\begin{array}{l}(1,047- \\
4,844)\end{array}$ \\
\hline Lengkap & 13 & 28,9 & 43 & 47,8 & & \\
\hline $\begin{array}{c}\text { Riwayat } \\
\text { Penyakit } \\
\text { Infeksi } \\
\end{array}$ & & & & & & $7,0^{7}$ \\
\hline Ada Riwayat & 28 & 62,2 & 17 & 18,9 & 0,000 & $(3,174-$ \\
\hline $\begin{array}{c}\text { Tidak Ada } \\
\text { Riwayat }\end{array}$ & 17 & 37,8 & 73 & 81,1 & & $15,758)$ \\
\hline Total & 45 & 100 & 90 & 100 & & \\
\hline
\end{tabular}

Hasil yang disajikan pada tabel 3 menunjukan bahwa tidak ada hubungan antara status imunisasi dengan kejadian stunting $(\mathrm{p}=0,056)$, dan ada hubungan antara riwayat penyakit infeksi dengan kejadian stunting pada balita $(\mathrm{p}=0,000), \mathrm{OR}=7,073$ $(3,174-15,758)$, yang artinya balita yang memiliki riwayat penyakit infeksi berpeluang mengalami stunting sebesar 7 kali lebih besar dibandingkan dengan balita yang tidak memiliki riwayat penyakit infeksi.

\section{PEMBAHASAN}

\section{Gambaran Stunting, Status Imunisasi dan Riwayat Penyakit Infeksi}

Stunting mencerminkan suatu proses kegagalan mencapai pertumbuhan linier (tinggi badan) yang potensial sebagai akibat dari status gizi. Stunting merupakan keadaan status gizi seseorang berdasarkan z-skor tinggi badan (TB) terhadap umur (U) dimana terletak pada $<-2$ SD. Suatu kondisi dimana gagalnya pertumbuhan pada balita yang disebabkan oleh kurangnya gizi kronis sehingga balita terlalu pendek dari balitabalita seusianya dan kondisi stunting ini nampak setelah balita berusia 2 tahun.

Berdasarkan hasil penelitian, dari 135 balita yang menjadi responden, sebagian besar balita lahir pada tahun 2016, sedangkan dilihat dari jenis kelamin jumlah balita yang 
berjenis kelamin laki-laki sebanyak 73 balita sedangkan balita yang berjenis kelamin perempuan sebanyak 62 balita. Penelitian ini tidak melakukan analisis pada variabel umur karena semua sampel dalam penelitian ini adalah balita berumur 24-59 bulan, secara teoritis beberapa permasalahan umum diantaranya balita susah makan dibarengi dengan kualitas dan kuantitas ASI yang semakin berkurang dengan bertambahnya umur anak. Sehingga sampai usia 24 bulan bisa dianggap sebagai masa adaptasi untuk dapat mengkonsumsi makanan yang sesuai dengan zat gizi. Pada usia 24 bulan ke atas balita akan mulai mampu melahap makanan lebih banyak. Oleh karena itu masalah gizi termasuk stunting tidak banyak dialami oleh anak usia $>24$ bulan.(14) Penelitian ini juga tidak melakukan analisis pada variabel jenis kelamin, walaupun secara teori jenis kelamin dapat menentukan besaran kebutuhan gizi bagi seseorang sehingga terdapat keterkaitan antara status gizi dan jenis kelamin. Perbedaan besarnya kebutuhan gizi tersebut dipengaruhi karena adanya perbedaan komposisi tubuh antara laki-laki dan perempuan. Sehingga jumlah asupan yang harus dikonsumsi pun lebih banyak.

Sebagian besar responden dalam penelitian ini tidak mendapatkan imunisasi lengkap. Berdasarkan informasi dari Puskesmas Citarip Kota Bandung Cakupan Imunisasi dasar lengkap sudah mecapai target nasional, tetapi memang masih cukup banyak bayi dan balita yang tidak mendapatkan imunisasi dasar lengkap. Salah satu penyebab rendahnya cakupan imunisasi adalah masih kurangnya pengetahuan pada ibu yang memiliki bayi untuk mengimunisasi bayinya.Hasil penelitian ini jauh lebih rendah dibandingkan dengan penelitian sebelumnya yang dilakukan di Puskesmas Cancaekek Kota Bandung, yang menunjukan hasil cakupan imuniasi dasar lengkap sebesar $88 \%$. Dari hasil penelitian tersebut menyatakan bahwa faktor yang dapat memengaruhi seseorang berprilaku menentukkan anaknya untuk diberi imunisasi adalah pengetahuan.

Sebagian besar balita yang menjadi responden dalam penelitian ini tidak memiliki riwayat penyakit infeksi. Penyakit infeksi yang dilihat pada studi ini adalah riwayat balita menderita penyakit diare dan riwayat balita menderita penyakit Infeksi Saluran Pernapasan Akut (ISPA). Dari seluruh sampel terdapat $8 \quad(5,9 \%)$ balita yang memiliki riwayat penyakit diare dan $40(29,6 \%)$ yang memiliki riwayat penyakit ISPA.Balita yang memiliki penyakit infeksi akan menimbulkan gejala-gejala seperti tidak merasa lapar, tidak mau makan, mulut terasa pahit yang dapat menyebabkan asupan gizi pada anak akan berkurang sehingga akan mempengaruhi tumbuh kembang pada anak. Makanan untuk anak harus mengandung kualitas dan kuantitas cukup untuk menghasilkan kesehatan yang baik.

Kekurangan gizi akan mengakibatkan anak mudah terserang penyakit. Hal ini kemungkinan dapat disebabkan oleh beberapa faktor diantaranya asupan makanan yang diterima setiap harinya tidak sesuai dengan kebutuhan untuk beraktivitas. Adanya penyakit infeksi yang diderita oleh balita me ngakibatkan daya tahan tubuh menurun dan berdampak pada penurunan berat badan dan kehilangan energi dalam tubuh.

\section{Hubungan Status Imunisasi dengan Kejadian Stunting Pada Balita}

Penelitian ini tidak dapat membuktikan adanya hubungan antara status imunisasi dengan kejadian stunting. Sejalan dengan penelitian sebelumnya di Depok, yang menyatakan bahwa tidak ada hubungan yang bermakna antara status imunisasi dengan kejadian stunting, dimana diperoleh $P$-value $=$ 0,495.(18) Sejalan juga dengan penelitian di Bandar Lampung, yang menyatakan tidak ada hubungan antara status imunisasi dengan kejadian stunting pada balita, dimana diperoleh $P$-value $=0,380 .(19)$. Sedangkan beberapa penelitian sebelumnya menyatakan ada hubungan yang dilakukan di Klaten yang menyebutkan bahwa adanya hubungan yang signifikan antara status imunisasi dengan kejadian stunting dan memperoleh $P$-value $=$ 
0,007.(20)

Berdasarkan hasil penelitian, pada kelompok kasus terdapat $71,1 \%$ balita dengan status imunisasi tidak lengkap, hal ini disebabkan karena dilihat dari buku KIA terdapat bahwa balita tersebut diimunisasi akan tetapi ada bulan-bulan tertentu yang terlewat serta dalam buku ksehatan ibu dan anak (KIA) tersebut balita tidak jadi di imunisasi karena sedang demam atau harus dirujuk ke ruang Manajemen Terpadu Balita Sakit (MTBS). Menurut teori bahwa apabila tidak lengkapnya imunisasi dapat menyebabkan imunitas balita menjadi lemah, sehingga mudah untuk terserang infeksi. Apabila balita mengalami infeksi dan dibiarkan begitu saja, maka dapat berisiko menjadi stunting.

Pada kelompok kasus juga terdapat $29,9 \%$ balita dengan status imunisasi lengkap. Hal ini disebabkan meskipun imunisasi balita tersebut lengkap bukan berarti terbebas dari stunting karena ada beberapa faktor lain yang dapat menyebabkan stunting. Ada beberapa faktor yang menyebabkan terjadinya stunting diantaranya pengetahuan, pemberian ASI ekslusif, sanitasi yang buruk karena belum adanya jamban, saluran air yang menggenang, tempat sampah terbuka, dan lingkungan yang tidak bersih, pendidikan orang tua, pekerjaan orangtua, pendapatan orangtua, jenis kelamin balita, Berat Badan Lahir Rendah (BBLR), panjang lahir balita dan ibu yang jarang mencuci tangan menggunakan air bersih dan sabun.

Menurut peneliti, imunisasi untuk menjaga kekebalan balita hingga pada masa dewasanya. Dan imunisasi dasar lengkap merupakan imunisasi wajib yang harus diberikan pada balita. Pada buku KIA sebagian besar balita berstatus imunisasi yang lengkap akan tetapi ada beberapa balita yang status imunisasi tidak lengkap. Ini dikarenakan balita yang tidak jadi imunisasi dan balita yang dirujuk ke ruang MTBS sehingga pada bulan selanjutnya mendapat imunisasi yang baru dan imunisasi bulan kemarin terlewat. Ada juga balita yang diberikan imunisasinya tidak sesuai jadwalnya, seperti vaksin BCG yang seharusnya diberikan di bulan kedua tetapi diberikan pada bulan keempat. Pemberian imunisasi pada balita terutama saat masih balita merupakan hal yang sangat penting, itu dikarenakan apabila balita diberi imunisasi maka dapat meningkatkan daya tahan tubuhnya. Apabila balita tidak diimunisasi dari sejak balita maka dapat mudah terserang penyakit infeksi, nafsu makan yang kurang dan gangguan absorpsi zat gizi yang akan mengakibatkan kebutuhan zat gizi balita semakin tinggi. Kebutuhan zat gizi makro maupun mikro sangatlah tinggi pada usia balita 2 tahun pertama kehidupan untuk mendukung fase pertumbuhan yang pesat.(24)

\section{Hubungan Riwayat Penyakit Infeksi dengan Kejadian Stunting Pada Balita}

Penelitian ini dapat membuktikan adanya hubungan antara riwayat penyakit infeksi dengan kejadian stunting. Sejalan dengan penelitian sebelumnya yang dilakukan di Kabupaten Brebes, yang menunjukkan ada hubungan penyakit infeksi dengan stunting, dimana diperoleh $P$-value $=0,001$ dan OR $=17$, yang berarti bahwa balita yang menderita penyakit infeksi memiliki risiko 17 kali mengalami stunting daripada balita yang tidak menderita penyakit infeksi.(25). Sejalan juga dengan penelitian di Kota Palu, bahwa terdapat hubungan penyakit infeksi dengan kejadian stunting, dimana diperoleh $P$-value $=$ 0,000 dan $\mathrm{OR}=3,4$, yang berarti balita yang menderita penyakit infeksi berisiko 3,4 kali lebih besar mengalami stunting dibanding dengan balita yang tidak menderita penyakit infeksi. Sedangkan penelitian di Kabupaten Bolaang Mongondow Induk menyatakan sebaliknya, tidak ada hubungan antara riwayat penyakit infeksi dengan kejadian stunting.

Berdasarkan hasil penelitian, pada kelompok kasus terdapat $62,2 \%$ balita dengan adanya riwayat penyakit infeksi hal ini disebabkan karena beberapa balita yang mempunyai riwayat penyakit infeksi dan tidak mempunyai status imunisasi yang 
lengkap pada buku KIA nya. Menurut teori bahwa upaya untuk memperoleh kekebalan tubuh terhadap penyakit infeksi adalah dengan melakukan imunisasi, imunisasi ini adalah salah satu bentuk intervensi kesehatan dalam sistem kesehatan nasional yang sangat efektif untuk menurunkan angka kematian balita. Pada kelompok kasus juga terdapat $37,8 \%$ balita dengan tidak adanya riwayat penyakit infeksi. Hal ini disebabkan meskipun balita tersebut tidak memiliki riwayat penyakit infeksi akan tetapi ada faktor lain yang dapat menyebabkan stunting pada balita. Penyakit infeksi dapat mengganggu pertumbuhan dan perkembangan balita. penyakit infeksi yang sering diderita oleh balita atau balita ialah diare dan ISPA. Balita yang kurang gizi akan memiliki daya tahan tubuh yang rendah, jatuh sakit, sehingga mengurangi kapasitasnya untuk melawan penyakit dan sebagainya.

Menurut peneliti, penyakit infeksi dan stunting memiliki keterkaitan dimana penyakit infeksi dapat mempengaruhi asupan gizi balita dan apabila asupan gizi balita semakin menurun dapat terjadi stunting. Pada buku MTBS banyak balita dengan kategori stunting yang menderita penyakit infeksi baik diare atau ISPA. Dalam buku KIA pun banyak balita yang tidak jadi diimunisasi dikarenakan harus dirujuk ke ruang MTBS bahkan yang menderita penyakit infeksinya pun berulang. Seperti dalam satu tahun balita 1-3 kali menderita penyakit infeksi. Tingginya kejadian diare disertai gangguan penyerapan dan tingkat kehilangan zat gizi secara berulang pada balita akan menyebabkan terganggunya proses pertumbuhan. Balita stunting dengan prevalensi diare yang tinggi memiliki daya imun yang lebih rendah, sehingga jika terpapar polusi udara atau mengonsumsi makanan dan minuman yang memicu dapat menimbulkan penyakit ISPA seperti batuk dan pilek.Semakin baik status gizi balita, akan semakin besar pula peluang tidak menderita penyakit infeksi. Status gizi yang baik umumnya akan meningkatkan resistensi tubuh terhadap penyakit infeksi seperti diare, kecacingan dan ISPA.
Lingkungan didalam rumah yang penuh dengan asap rokok akan menyebabkan balita lebih mudah terserang penyakit ISPA dan status imunisasi yang rendah selain memudahkan balita terserang infeksi juga akan menyebabkan durasi waktu penyakit infeksi tersebut semakin lama.

\section{KESIMPULAN}

Gambaran kejadian stunting pada balita sebagian besar balita stunting memiliki status imunisasi yang tidak lengkap dan memiliki riwayat penyakit infeksi seperti diare atau ISPA bahkan keduanya.Tidak ada hubungan yang signifikan antara status imunisasi dengan kejadian stunting pada balita.Ada hubungan yang signifikan antara riwayat penyakit infeksi dengan kejadian stunting pada balita.

\section{SARAN}

Disarankan kepada Puskesmas mengoptimalkan program-program yang pencegahan stunting seperti cakupan imunisasi minimal sesuai dengan standar nasional dan juga untuk melakukan deteksi terhadap balita yang perna mengalami penyakit infeksi guna melakukan pencegahan sejak dini.Disarankan juga kepada masyarakat khususnya ibu yang memiliki bayi dan balita untuk selalu memeriksakan anaknya ke posyandu untuk melakukan pemantauan tumbuh kembang anak.

\section{DAFTAR PUSTAKA}

Agustia R, Rahman N, Hermiyanty H. Faktor Risiko Kejadian Stunting Pada Balita Usia 12-59 Bulan Di Wilayah Tambang Poboya, Kota Palu. Ghidza J Gizi dan Kesehat. 2018;2(2):59-62.

Badriyah L, Syafiq A. The association between sanitation, hygiene, and stunting in children under two-years (an analysis of Indonesia's Basic Health Research, 2013). Makara J Heal Res [Internet]. 2017;21(2):1. Available from: 
https://scholarhub.ui.ac.id/mjhr/vol21/iss2 $11 /$

Black RE, Victora CG, Walker SP, Bhutta ZA, Christian P, De Onis M, et al. Maternal and child undernutrition and overweight in low-income and middle-income countries. Lancet. 2013;382(9890):42751.

Cumming O, Cairncross S. Can water, sanitation and hygiene help eliminate stunting? Current evidence and policy implications. Matern Child Nutr [Internet]. 2016;12:91-105. Available from:

http://jurnal.fkm.untad.ac.id/index.php/ghi $\mathrm{dza} /$ article/view/10

Dhirah UH, Lestari S, Marniati M. Waspada Penyakit Difteri Cegah Dengan Imunisasi Lanjutan Pentabio Pada Balita Usia 0-18 Bulan. J Pengabdi Kpd Masy [Internet]. 2019;1(2):24-7. Available from: http://jurnal.uui.ac.id/index.php/jpkmk/art icle/view/812

Data P, Informasi Kemenkes RI. Situasi Balita Pendek (Stunting) di Indonesia. P Kemenkes RI, Atmarita, Y Zahraini, A Dharmawan, Bul Jendela Data dan Inf Kesehat Ed I Tahun. 2018;1-13.

Damanik PEG. Hubungan Status Gizi, Pemberian ASI Eksklusif, Status Imunisasi Dasar dengan Kejadian Infeksi Saluran Pernapasan Akut (ISPA) pada Anak Usia 12-24 Bulan di Wilayah Kerja Puskesmas Glugur Darat Kota Medan. 2014;

Fitri L. Hubungan Bblr Dan Asi Ekslusif Dengan Kejadian Stunting Di Puskesmas Lima Puluh Pekanbaru. J Endur [Internet]. 2018;3(1):131. Available from: http://ejournal.1ldikti10.id/index.php/endu rance/article/view/1767

Febriani CA, Perdana AA, Humairoh $\mathrm{H}$. Faktor kejadian stunting balita berusia 623 bulan di Provinsi Lampung. J Dunia Kesmas. 2018;7(3).

Gross R, Schoeneberger H, Pfeifer H, Preuss H-J. The four dimensions of food and nutrition security: definitions and concepts. SCN News [Internet].
2000;20(20):20-5. Available from: https://www.cabdirect.org/cabdirect/abstra $\mathrm{ct} / 20003016751$

Hasan A, Kadarusman H. Akses ke Sarana Sanitasi Dasar sebagai Faktor Risiko Kejadian Stunting pada Balita Usia 6-59 Bulan. J Kesehat [Internet]. 2019;10(3):413-Available from: http://www.ejurnal.poltekkestjk.ac.id/index.php/JK/article/view/1451

Ikhtiarti W, Rahfiluddin MZ, Nugraheni SA. Faktor Determinan Yang Berhubungan Dengan Kejadian Stunting Pada Balita Usia 1-3 Tahun Di Wilayah Pesisir Kabupaten Brebes. J Kesehat Masy [Internet]. 2020;8(1):260-71. Available from:

https://ejournal3.undip.ac.id/index.php/jk $\mathrm{m} /$ index

Kemenkes RI. Hasil utama RISKESDAS 2018. Online) http//www depkes go $\mathrm{id} /$ resources/download/infoterkini/materi rakorpop 2018/Hasil\% 20Riskesdas. $2018 ; 202018$.

Kemiskinan TNPP. 100 kabupaten/kota prioritas untuk intervensi anak kerdil (stunting). Jakarta Tim Nas Percepatan Penanggulangan Kemiskin. 2017; hp/JKMK/article/view/2072

Khairiyah D, Fayasari A. Perilaku higiene dan sanitasi meningkatkan risiko kejadian stunting balita usia 12-59 bulan di Banten. Ilmu Gizi Indones [Internet]. 2020;3(2):123-Available from: http://ilgi.respati.ac.id/index.php/ilgi2017/ Lupiani M, Ilyas H, Oktiani K. Hubungan Status Imunisasi, Pendidikan Ibu, Sikap Ibu Dan Pendapatan Keluarga Dengan Status Gizi Balita Di Kelurahan Beringin Jaya Kecamatan Kemiling Kota Bandar Lampung. Holistik J Kesehat. 2018;12(3):146-53.

Mandasari NF, Nawangsih UHE. Hubungan Karakteristik Ibu dengan Status Gizi Balita di Posyandu Kuncup Mekar Dusun Karanganyar desa Banyubiru Kec. Dukun Kab. Magelang Tahun 2010 [Internet]. STIKES'Aisyiyah Yogyakarta; 2010. Available

from: 
http://digilib.unisayogya.ac.id/1667/

Mirani N. Faktor Risiko Stunting Pada Balita di Wilayah Kerja Puskesmas Idi Timur Kabupaten Aceh Timur. J EDUKES (Jurnal Penelit Edukasi Kesehatan) [Internet]. 2018;59-70. Available from: http://e-

jurnal.stikesydb.ac.id/index.php/edukes/ar ticle/view/7

Organization WH. UNICEF/WHO/The World Bank Group joint child malnutrition estimates: levels and trends in child malnutrition: key findings of the 2020 edition. 2020; Available from: https://apps.who.int/iris/bitstream/handle/ 10665/331621/9789240003576-eng.pdf

Putri MS, Kapantow N, Kawengian S. Hubungan antara riwayat penyakit infeksi dengan status gizi pada anak batita di Desa Mopusi Kecamatan Lolayan Kabupaten Bolaang Mongondow. eBiomedik [Internet]. 2015;3(2). Available from:

https://ejournal.unsrat.ac.id/index.php/ebi omedik/article/view/8461

Rahman A, Nur AF. Hubungan pemberian asi eksklusif dengan kejadian penyakit infeksi saluran pernafasan akut pada anak balita di wilayah kerja puskesmas managaisaki. Heal Tadulako J (Jurnal Kesehat Tadulako) [Internet]. 2015;1(1). Available from: http://jurnal.untad.ac.id/jurnal/index.php/ HealthyTadulako/article/view/5732

Rahmawati I, Sudargo T, Paramastri I. Pengaruh penyuluhan dengan media audio visual terhadap peningkatan pengetahuan, sikap dan perilaku ibu balita gizi kurang dan buruk di Kabupaten Kotawaringin Barat Propinsi Kalimantan Tengah. J gizi Klin Indones. 2007;4(2):69-77.

Richter LM, Daelmans B, Lombardi J, Heymann J, Boo FL, Behrman JR, et al. Investing in the foundation of sustainable development: pathways to scale up for early childhood development. Lancet [Internet]. 2017; 389 (10064): 103-18. Available from:

https://www.sciencedirect.com/science/art
icle/abs/pii/S0140673616316981

Rumahorbo RM. Faktor-Faktor Yang Mempengaruhi Tumbuh Kembang Balita Di Wilayah Kerja Puskesmas Pancur Batu Kabupaten Deli Serdang Tahun 2019. CHMK Heal J [Internet]. 2020;4(2):15865. Available from: http://cyberchmk.net/ojs/index.php/kesehatan/article/ view/795

Rohmatun NY. Hubungan Tingkat Pendidikan Ibu Dan Pemberian ASI Eksklusif Dengan Kejadian Stunting Pada Balita Di Desa Sidowarno Kecamatan Wonosari Kabupaten Klaten [Internet]. Universitas Muhammadiyah Surakarta; 2014. Available from: http://eprints.ums.ac.id/31231/

Rollins NC, Bhandari N, Hajeebhoy N, Horton S, Lutter CK, Martines JC, et al. Why invest, and what it will take to improve breastfeeding practices? Lancet [Internet]. 2016;387(10017):491-504. Available from: https://www.sciencedirect.com/science/art icle/abs/pii/S0140673615010442

Setyawati VAV. Kajian Stunting Berdasarkan Umur dan Jenis Kelamin di Kota Semarang. Proceeding of The URECOL. 2018;834-8.

Sutriyawan A, Andini M, Dian R. Hubungan Imunisasi, Asi Eksklusif Dan Peran Kader Dengan Tumbuh Kembang Balita Di Puskesmas Rancaekek Tahun 2019. J Mitra Kencana Keperawatan dan Kebidanan. 2019;3(2).

Sutriyawan A, Nadhira CC. Kejadian Stunting Pada Balita Di Upt Puskesmas Citarip Kota Bandung. J Kesmas (Kesehatan Masyarakat) Khatulistiwa [Internet]. 2020;7(2):79-88. Available from: http://openjurnal.unmuhpnk.ac.id/index.p article/view/137 